\title{
Hacking assignment practice: finding creativity and power in the fissures and cracks of learning and teaching
}

\section{Sandra Abegglen}

London Metropolitan University, UK

\section{Tom Burns}

London Metropolitan University, UK

\section{Sandra Sinfield}

London Metropolitan University, UK

\begin{abstract}
This paper explores integrated peer mentoring in the context of offering students an element of choice in their assignments. We decided to undertake a pilot study with a group of first year undergraduate education-studies students who come from non-traditional backgrounds, but the concept is widely applicable. We argue that creative approaches to assignment practice can promote inclusion and give students, not traditionally welcome in the academy, ownership, voice and pride.
\end{abstract}

Keywords: Non-traditional students; integrated peer mentoring; assignment practice.

\section{Introduction}

Working in a university that is proudly dedicated to widening participation, we have long wanted a paradigm shift in assignment practices not just because social inclusion is especially important in diverse classrooms, but rather because we want practices that excite and challenge all students. We argue that assignment practice should allow students to showcase their learning, rather than reward conformity, compliance and, arguably, already-existing cultural capital (Bourdieu, 1984; Lillis, 2001). Hence, we wanted assignment practices that allow students to develop and demonstrate their learning in generative, discursive and meaningful ways; approaches that take account of the 
importance of issues of identity and institutional relationships of power and authority that surround, and are embedded within, traditional assignment practice. The question, however, as Crème states, is:

Do we dare to allow our students to be more creative, or are we too afraid that it will upset our own categories and ways of thinking? (Crème, 2003, p. 276)

Cheng and Warren (2007) argue that students are more likely to be interested, and therefore motivated, if they are involved in the design of assignment tasks and/or if they can choose between different tasks. The present paper discusses the implications of 'hacking' traditional assignment practice in the context of a 30-week first year module (entitled 'Becoming an Educationalist') that we paired with a 15-week second-year peer mentoring module. We offered flexibility in the assignments with which students engaged, such that students could choose from and engage in a range of activities and miniprojects, allowing them space and time to follow their passions. We wanted assignments that created 'fissures and cracks'1 (Deleuze and Guattari, 1987) in which our students could learn from and be with (Nancy, 2000) each other. We will argue that creative approaches to assignment practice, when combined with embedded peer mentoring, fosters student achievement and well-being (Keenan, 2014), allowing students the opportunity to be with and learn from each other. "Being with" (Nancy, 2000, p. 85) is particularly important for our students who come from non-traditional backgrounds and who often struggle with academic practices (Abegglen et al., 2015). They need someone who they can rely on and refer to, because, as Nancy states:

There is no meaning if meaning is not shared, and not because there would be an ultimate or first signification that all beings have in common, but because meaning is itself the sharing of being. (Nancy, 2000, p.1).

\footnotetext{
1 In their work, 'A Thousand Plateau's', Deleuze and Guttari (1987) use the term "rhizome" to describe theory and research that allows for multiple, non-hierarchical entry and exit points in data representation and interpretation. As such, the 'rhizome has no beginning or end; it is always in the middle, between things, intervening, intermezzo' and through that allows the creation of new, although smooth, spaces - spaces that cut across boundaries imposed by vertical lines of hierarchies and order.
} 


\section{Don't waste student work}

In higher education $(\mathrm{HE})$, it could be said that typically information is transferred from the lecturer to the students: the assignment then transfers the information back to the lecturer in a reductive, recursive cycle. Whilst lectures may be good for transmitting information, arguably they are not effective in promoting thought or to change and develop attitudes (Bligh, 1998). We argue, in line with Mclnerney et al. (2009), that the regurgitative nature of the typical assignment fails to excite or engage the student. We therefore wanted to set assignments that truly engaged and challenged students, that allowed them to feel integrated and included (Tinto, 1998), rather than outsiders looking in (Sinfield, Burns and Holley, 2004).

With Crème (2003), we do not challenge the traditional academic essay per se as an assignment form, but its monolithic domination of university life. The essay can waste student work (Davies, 2011) engaging them in an unequal struggle with a disempowering academic practice where they spend too much time and energy in getting it right (Crème, 2003; Lillis, 2001), rather than harnessing their interest and creativity to engage with that which they want to understand or learn. We argue that more emancipatory and creative approaches to assignment practice, especially when coupled with fully integrated peer support, can help to close the access gap that traditionally exists and is fostered in UK HE. Instead of privileging an already capitalised elite, all students, including those from nontraditional backgrounds, or those with learning difficulties or a disability (Jamieson and Morgan, 2008), should be able to develop and grow to reach their potential and career goals. This seems possible when promoting ownership and engagement by allowing students' choice as to which assignment, or which assignment form, they wish to engage.

Peers, by definition, are close to each other in age, ability, status, ethnicity and other characteristics. (Walberg, 1998, p.x).

Moreover, peer learning fosters dialogic (Bakhtin, 1981) and social learning (Wenger, 2009 and 2010), and promotes 'students as partners' (Healey et al., 2014; Higher Education Academy, 2014). 
Hence, peer learning can help first-year undergraduate students with professional behaviours and practices (Allan, 2010), while strengthening their emerging academic identities and selves - and their self-efficacy (Fox and Stevenson, 2006) - all of which allows them to become successful learners and 'educators'.

\section{The modules and students in question}

To enhance student learning and foster alternative and integrative practice, we paired a first-year academic literacies module ('Becoming an Educationalist') with a second-year peer mentoring module ('Peer Mentoring in Practice'), whereby the second-year students mentored the first-years as part of the module itself: both modules were situated within the BA Hons Education Studies programme. Students on the two modules met on a weekly basis over a period of fifteen weeks in the autumn semester. All sessions took place in IT labs that gave all students access to e-resources.

Assignments for 'Becoming an Educationalist' included a small qualitative project on an aspect of studying at $\mathrm{HE}(30 \%)$; a summative reflective essay where students are encouraged to develop meta-cognitive awareness through their writing (40\%); and a portfolio providing evidence of engagement in creative projects chosen from a range that we offer: 'Blogging to Learn'; 'Interactive Performance' and 'Develop a Digital Me', or that they set themselves $(30 \%)$ - submitting the three projects of which they are the most proud. The aim of these creative projects and the element of choice, was to foster students' personal and professional development by giving them the freedom to explore and follow their passions, to re-territorialise academic space (Deleuze and Guattari, 1987) with engagement and creativity.

Peer mentor support of the first-years, fully integrated into both programmes, was both pastoral, facilitating belonging, and academic, facilitating first-year understanding of the academic milieu and the specific tasks with which they were wrestling. In the process both groups of students were co-learning (Freire, 1993 and 1998) especially in terms of their digital practice, as both were asked to reflect on their personal and academic progress on personal, yet publicly shared, blogs. 
Our students are proud of the outcomes of their projects and have contributed to this website in order to showcase and share some of their work, not only with their peers, but also a broader public: http://learning.londonmet.ac.uk/epacks/posters-digital/2 .

\section{Discussion}

When discussing alternative assignments that give options to students, one common critique is that this is an easy option for students in an over liberal-approach to learning and teaching. However, in practice, feedback from students reveals that they are more discomforted by the idea of social interaction and of producing a digital artefact than they are by having to produce an essay. Our students are not academic or digital natives (Prensky, 2001), they do not segue easily into using their creativity or their e-devices for assignments, nor are they used to being encouraged to voice their opinion publicly (Tett, 2000). We argue that assignment-innovation forces students into zones of discomfort and of engagement. They cannot 'cut and paste', disengaging their selves from the assignment process. They have to think, engage, struggle: to develop an idea; to work with unfamiliar material or to use unfamiliar technology and to successfully work together with others to be able to finish and showcase their creative projects.

Project-based learning and multimodal meaning-making are not easy options; but, because of the meaningful discomfort and struggle, they can be transformative ones. The students fed back to us that these were the spaces and projects in which they felt themselves to "actively learn" and "become academic", where they were allowed to be with each other (Nancy, 2000) demonstrating their resilience, creativity and commitment. This is playful learning (Winnicott, 1971), not 'dumbed down', but learning that creates opportunities for our students to be fiercely alive and fiercely themselves as they navigate the threats of the transitional space of their emergent academic selves.

\section{Summary and recommendations}

We challenged our undergraduate students by setting a wider range of more difficult tasks than would normally be encountered within the first-year: they had to blog; to produce a

\footnotetext{
2 Shared with the consent and permission of the students.
} 
'Digital Me' using unfamiliar technology; to devise and deliver projects of their own choosing and to demonstrate their engagement through exhibitions, performances and showcases. All of these tasks terrified the students, at first. However, the pairing of the first-year students with the second-year mentors meant that they were supported as they struggled with unfamiliar tasks that, hard as they were, opened up spaces for playful, generative learning. The students were frightened at times, yes, but they were challenged to struggle meaningfully and with meaning itself, and they rose to that challenge in ways that surprised themselves and delighted us.

In this project our students demonstrated that assignment practice can be democratic (Dewey, 1997) and emancipatory (Freire, 1993 and 1998); but most of all they demonstrated the power of 'we'. As Nancy argues:

Being is always 'being with'....the essence of singularity: it is not individuality; it is $\ldots$ at one and the same time, infra-/individual and trans-individual, and always the two together. (Nancy, 2000, p.85)

Hence, by allowing our students to work (and struggle) with each other, joyful things happened. Our recommendation is that more courses should 'hack' traditional assignment practice and offer students choice in the assignments in which they engage and which they submit for assessment. Students should have the opportunity to be with and learn from each other. If students are taken seriously and their strengths are fostered, university practice could become truly inclusive.

\section{References}

Abegglen, S., Burns, T. and Sinfield, S. (2015) 'Voices from the margins: narratives of learning development in a digital age', Journal of Educational Innovation, Partnership and Change, 1(1), pp. 1-8. Available at: https://193.60.48.124/index.php/studentchangeagents/article/view/148 (Accessed 1st July 2015). 
Allan, H. (2010) 'Mentoring overseas nurses: barriers to effective and non-discriminatory mentoring practices', Journal of Nursing Ethics, 17(5), pp. 603-613. http://dx.doi.org/10.1177/0969733010368747

Bakhtin, M. (1981) The dialogic imagination: four essays. Austin: University of Texas Press.

Bligh, D. A. (1998) What's the use of lectures? $5^{\text {th }}$ edn. Exeter: Intellect.

Bourdieu, P. (1984) Distinction: a social critique of the judgment of taste. London: Routledge.

Cheng, W. and Warren, M. (2007) 'Online collaborative learning and assessment', in Frankland, S. (ed.) Enhancing teaching and learning through assessment: deriving an appropriate model. Dordrecht: Springer, pp. 198-213.

Crème, P. (2003) 'Why can't we allow students to be more creative?', Teaching in Higher Education, 8(2), pp. 273-277. http://dx.doi.org/10.1080/1356251032000052492

Davies, J. (2011) Don't waste student work. Science of Imagination Laboratory [Video] Available at: http://tedxtalks.ted.com/video/TEDxOttawa-Jim-Davies-Dont-Wast (Accessed: 1st July 2015).

Deleuze, G. and Guattari, F. (1987) A thousand plateaus: capitalism and schizophrenia. Minneapolis and London: University of Minnesota Press.

Dewey, J. (1997) Democracy and education: an introduction to the philosophy of education. New York: The Free Press.

Freire, P. (1993) Pedagogy of the oppressed. New York: Continuum.

Freire, P. (1998) Pedagogy of freedom: ethics, democracy and civic courage. Lanham: Rowman and Littlefield Publishers. 
Fox, A. and Stevenson, L. (2006) 'Exploring the effectiveness of peer mentoring of accounting and finance students in higher education', Accounting Education, 15(2), pp. 189-202.

Healey, M., Flint, A. and Harrington, K. (2014) Engagement through partnership: Students as partners in learning and teaching in higher education. York: Higher Education Academy. Available at:

https://www.heacademy.ac.uk/system/files/resources/engagement through partner ship.pdf (Accessed: 3 October 2016).

Jamieson, C. and Morgan, E. (2008) Managing dyslexia at university: a resource for students, academic and support staff. Oxon and New York: Routledge.

Keenan, C. (2014) Mapping student-led peer learning in the UK. York: Higher Education Academy. Available at: https://www.heacademy.ac.uk/system/files/resources/peer led learning keenan n ov 14-final.pdf (Accessed: 3 October 2016).

Lillis, T. M. (2001) Student writing: access, regulation, desire. London: Routledge.

Mclnerney, D. M., Brown, G. T. L. and Liem, G. A. D. (eds.) (2009) Student perspectives on assessment: what students can tell us about assessment for learning. Greenwich, CT: Information Age Publishing.

Nancy, J. L. (2000) Being singular plural. Stanford, CA: Stanford University Press.

Prensky, M. (2001) 'Digital natives, digital immigrants', On the Horizon, 9(5), pp. 1-6. http://dx.doi.org/10.1108/10748120110424816

Sinfield, S., Burns, T. and Holley, D. (2004) 'Outsiders looking in or insiders looking out? Widening participation in a post-1992 university', in Satterthwaite, J., Atkinson, E. and Martin, W. (eds.) The disciplining of education: new languages of power and resistance. Stoke on Trent: Trentham Books, pp. 137-152. 
Tett, L. (2000) 'I'm working class and proud of it' - gendered experiences of nontraditional participants in higher education', Gender and Education, 12(2), pp. 183194. http://dx.doi.org/10.1080/09540250050009993

Higher Education Academy (2014) Framework for partnership in learning and teaching in higher education. York: The Higher Education Academy. Available at: https://www.heacademy.ac.uk/system/files/resources/hea framework for partnersh ip in learning and teaching.pdf (Accessed: 3 October 2016).

Tinto, V. (1998) 'Colleges as communities: taking research on student persistence seriously', Review of Higher Education, 21(2), pp. 167-177.

Walberg, H. J. (1998) 'Foreword', in Topping, K. and Ehly, S. (eds.) Peer-assisted learning. Mahwah, NJ: Laurence Erlbaum Associates, pp. ix-xii.

Wenger, E. (2009) 'Social learning capability: four essays on innovation and learning in social systems', Social Innovation, Sociedade e Trabalho. Booklets 12 - separate supplement. Lisbon: MTSS/GEP \& EQUAL. Available at: http://wengertrayner.com/wp-content/uploads/2011/12/09-04-17-Social-learning-capabilityv2.1.pdf (Accessed: 3 October 2016).

Wenger, E. (2010) 'Communities of practice and social learning systems: the career of a concept', in Blackmore, C. (ed.) Social learning systems and communities of practice. London: Springer and The Open University, pp. 179-198.

Winnicott, D. W. (1971) Playing and reality. London: Tavistock.

\section{Author details}

Sandra Abegglen is a Senior Lecturer in Education Studies and course leader of the BA Honours Education Studies at London Metropolitan University. Her areas of expertise include peer-to-peer support and experiential learning. 
Tom Burns is a Senior Lecturer with the Centre for Professional and Educational Development, London Metropolitan University. His area of expertise is creativity as emancipatory practice.

Sandra Sinfield is a Senior Lecturer with the Centre for Professional and Educational Development, London Metropolitan University. Her area of interest is creativity as emancipatory practice. 